\title{
New record and range expansion of Masticophis lateralis (Hallowell, 1853) (Squamata, Colubridae) into western Baja California Sur, Mexico
}

\author{
Aaron Michael Goodman ${ }^{1}$ Lauren Alyse Esposito ${ }^{1}$, Perla Lucia Ponce ${ }^{2}$, Ashley Rose Sauer ${ }^{3}$, \\ Eric Olaf Stiner ${ }^{4}$, Sara Ruane ${ }^{5}$
}

1 Institute for Biodiversity Science and Sustainability, California Academy of Sciences, 55 Music Concourse Drive, San Francisco, CA 94118, USA. 2 Contra Costa College, 2600 Mission Bell Drive, San Pablo, CA 94806, USA. 3 San José State University, 1 Washington Square, San Jose, CA 95192, USA. 4 Islands and Seas, 2254 38th Ave Oakland, CA 94601, USA. 5 Department of Biological Sciences, 206 Boyden Hall, Rutgers University, 195 University Ave, Newark, NJ 07102, USA.

Corresponding author: Aaron M. Goodman, agoodman@calacademy.org

\begin{abstract}
A specimen of Masticophis lateralis (Hallowell, 1853) was found and photographed in the outskirts of San Juanico Bay, Baja California Sur, Mexico. This record fills in a gap of the distribution of this species along both coasts of Baja California Sur.
\end{abstract}

\section{Key words}

Desert, distribution, San Juanico Bay, Striped Racer.

\section{Introduction}

Masticophis (Baird \& Girard, 1853) is a relatively small genus (11 species) of harmless colubrid snakes (Colubridae, Colubrinae), whose distribution ranges from the southern United States to northern South America (Powell et al. 2016). Distinctive characteristics of the genus include a slender long body, a bell-shaped elongate frontal scale, and dorsal scales arranged in 13 rows (Wilson 1996). The California Whipsnake or Striped Racer, Masticophis lateralis (Hallowell, 1853), is a fairly common, fast-moving, medium-sized diurnal species with a total length of 90-152 cm (Wilson 1996, Uetz 2012). This species has contiguous distribution from Trinity
County, California, west of the Sierra Nevada Mountains to northwestern Baja, at altitudes between 0-2250 m (Bogert 1930, Jennings 1983, Grismer and Marhdt 1996, Wilson 1996, Grismer 2002). Habitat preferences for this species varies considerably, including along the California coast and in the foothills, the chaparral of northern Baja, mixed deciduous and pine forests of the Sierra de Juárez, and deserts and canyons of Sierra San Pedro (Grismer and Marhdt 1996, Grismer and McGuire 1993, Wilson 1996, Grismer 2002). Masticophis aurigulus (Cope, 1861), M. fulginosis, and M. barbouri (Van Denburgh \& Slevin, 1921) are sympatric in some regions of Baja California Sur (Uetz 2012). Although this species is also found within isolated populations south of Cañon 
de los Reyes to the north of La Paz (Jennings 1983, Grismer 2002), we report a new record of this species extending to the western side of the peninsula.

\section{Methods}

While exploring the foothills east of San Juanico Bay, Baja California Sur, Mexico (Fig. 1) during a 10-day long field course hosted by the Islands and Seas Field Station, a single individual of $M$. lateralis was found climbing through the branches of a Colubrina viridis (M.E.Jones) M.C.Johnst. (family Rhamnaceae) within a ravine perpendicular to a cliff face. The specimen was captured by hand and made no attempts to bite when handled. The snake appeared to be in good overall condition although its tail was quite blunt, which indicates a previous loss of the tail tip. The specimen was not collected because there was no collection permit. However, the external anatomy and in-situ environment of this specimen were documented with photographs and the snake was identified unambiguously (Figs 2, 3). The specimen was released after identification. This region has previously been surveyed during 2016 and 2017 and only Masticophis fulginosis (Cope, 1895) was observed during those trips.

\section{Results}

\section{Masticophis lateralis (Hallowell, 1853)}

New records. (Fig. 1.) Mexico: Baja California Sur: ca 15 $\mathrm{km}$ E of San Juanico Bay $\left(26^{\circ} 19.187^{\prime} \mathrm{N}, 112^{\circ} 23.904^{\prime} \mathrm{W}\right.$; WGS84; alt. 295 m), observed by Aaron Goodman, Lauren Esposito, W. Brian Simison, Eric Stiner, Perla Ponce, Ashley Sauer \& Sara Ruane, 29 June 2018 (09:45 h).

Identification. The specimen was identified as M. lateralis based on the following diagnostic characters: having 8 supralabial scales; 17 dorsal mid-body scale rows; a dark olive-grey dorsum; a single white/cream lateral longitudinal stripe 2 scales in width on scale rows 3 and 4 counting from the venter; and a mottled grey-white pattern along the supralabials anterior to the eye (Figs 2, 3). This specimen had an additional mottled stripe from the supraocular to the prenasal, wrapping around the rostral scales, and a pink venter which faded to white anteriorly (Figs 2, 3).

The Species identification was initially based on information by Grismer (2002), with additional information by Riemer (1953), Grismer (1990), and Wilson (1996). This specimen was differentiated from M. aurigulus and M. barbouri in having the roughly square loreal scale, a faint temporal spot was present, presence of mottling as previously described, and primary mid-dorsal stripes on the third and fourth scale rows terminating at the tail (Grismer 1990). Masticophis aurigulus and M. fuliginosis possess a loreal scale which is twice as high as it is long, a prominent temporal spot, no ventral mottling, a clear white line along the preocular, prenasal, postnasal and rostral scales, and the mid-dorsal stripe

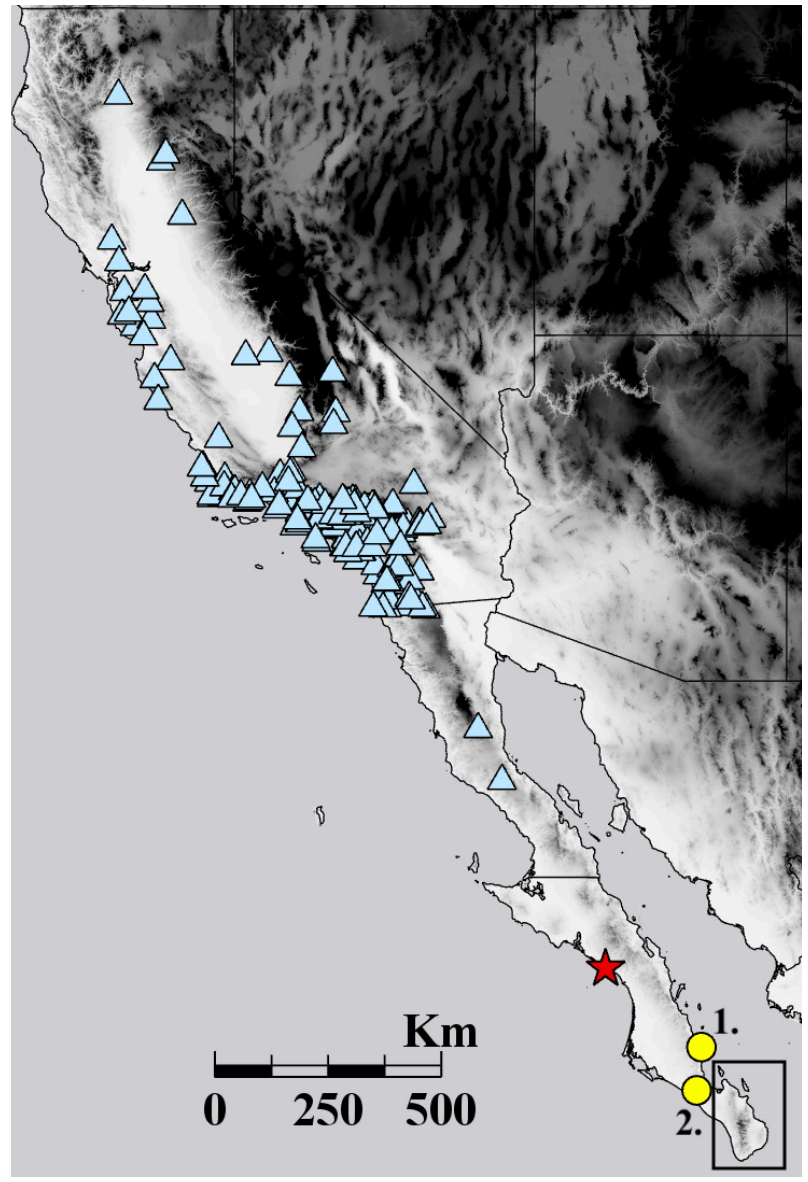

Figure 1. Geographic Distribution of Masticophis lateralis. Blue triangles represent previously collected specimens collected from 1818-2017 (iDigBio 2018, http://www.idigbio.org/portal). The red star indicates the specimen described here from from San Juanico Bay, Baja California Sur, Mexico. Yellow circles represent two specimens previously collected in southeast Baja California Sur (iDigBio 2018, http://www.idigbio.org/portal): 1. Hollingsworth et al. 2003. Fc - Uabc 1116, La Paz, Baja California Sur, Mexico. 2. Hollingsworth et al. 2004. Fc - Uabc 1260, La Paz, Baja California, Sur, Mexico. Black square indicates the Sarcocaulescent shrubland of Cabo San Lucas.

along the third and fourth dorsal scale rows terminates two-thirds down the body (Grismer 1990). Masticophis lateralis is differentiated from $M$. fuliginosis by obvious color differences in which $M$. fuliginosis has a light brown and black mottled dorsum becoming darker at the head with no prominent lateral stripe.

\section{Discussion}

Studies have demonstrated considerable flexibility in thermoregulatory behavior in $M$. lateralis as well as distinct species complexes within Masticophis due to vicariance events and barriers of isolation within North America (Hammerson 1979, O'Connell et al. 2017). This new record expands the range of $M$. lateralis into the westward plain desert of Baja California Sur; this is a new isolated environment compared to former records. Even though individuals of $M$. lateralis have been collected near La Paz (Fig. 1), our finding fills the distributional gap of this species from the Sarcocaulescent shrubland 


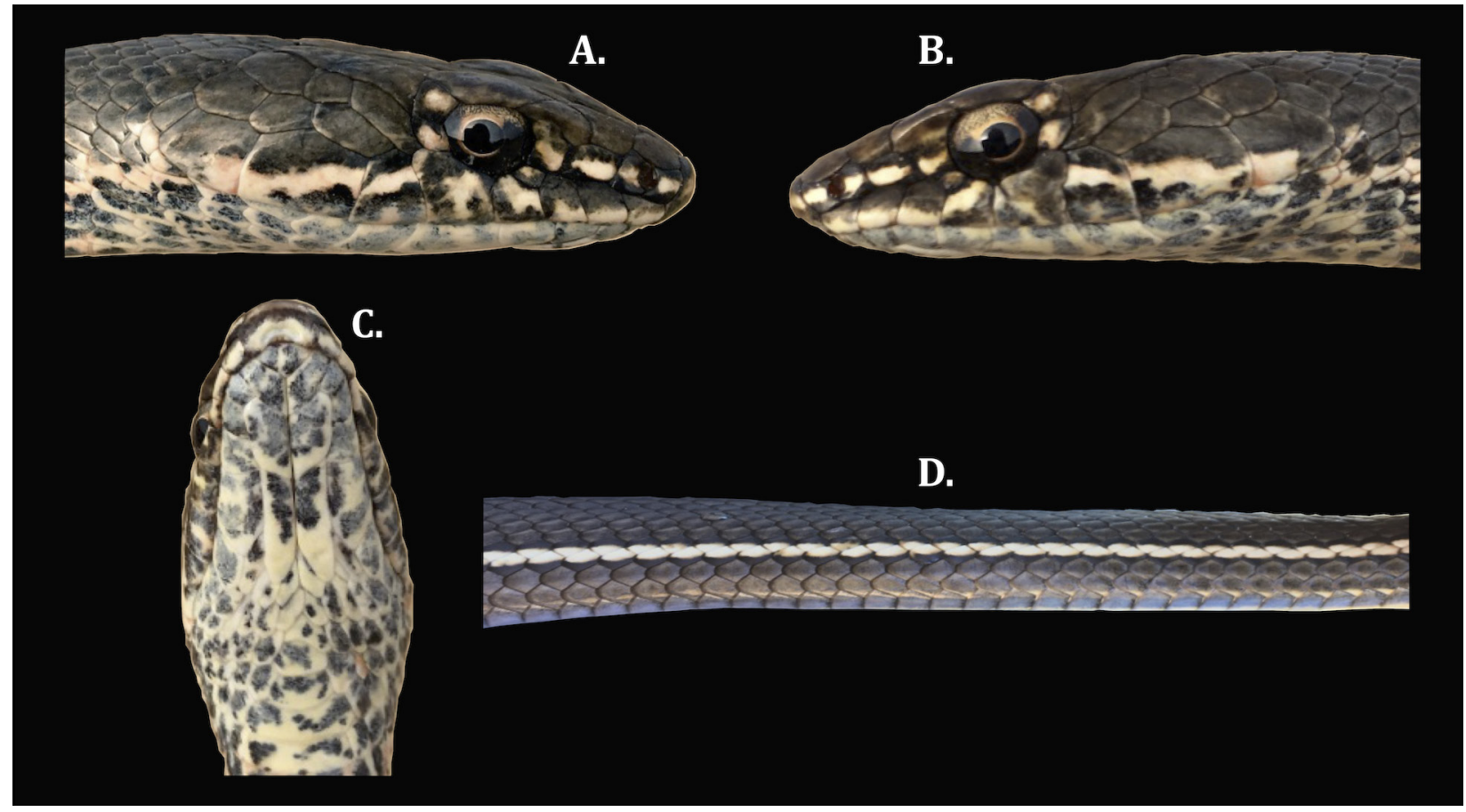

Figure 2. Masticophis lateralis from San Juanico Bay, Baja California Sur, Mexico. A. Right lateral head view. B. Left lateral head view. C. Ventral head view. D. Lateral body view. Photographs by S. Ruane.

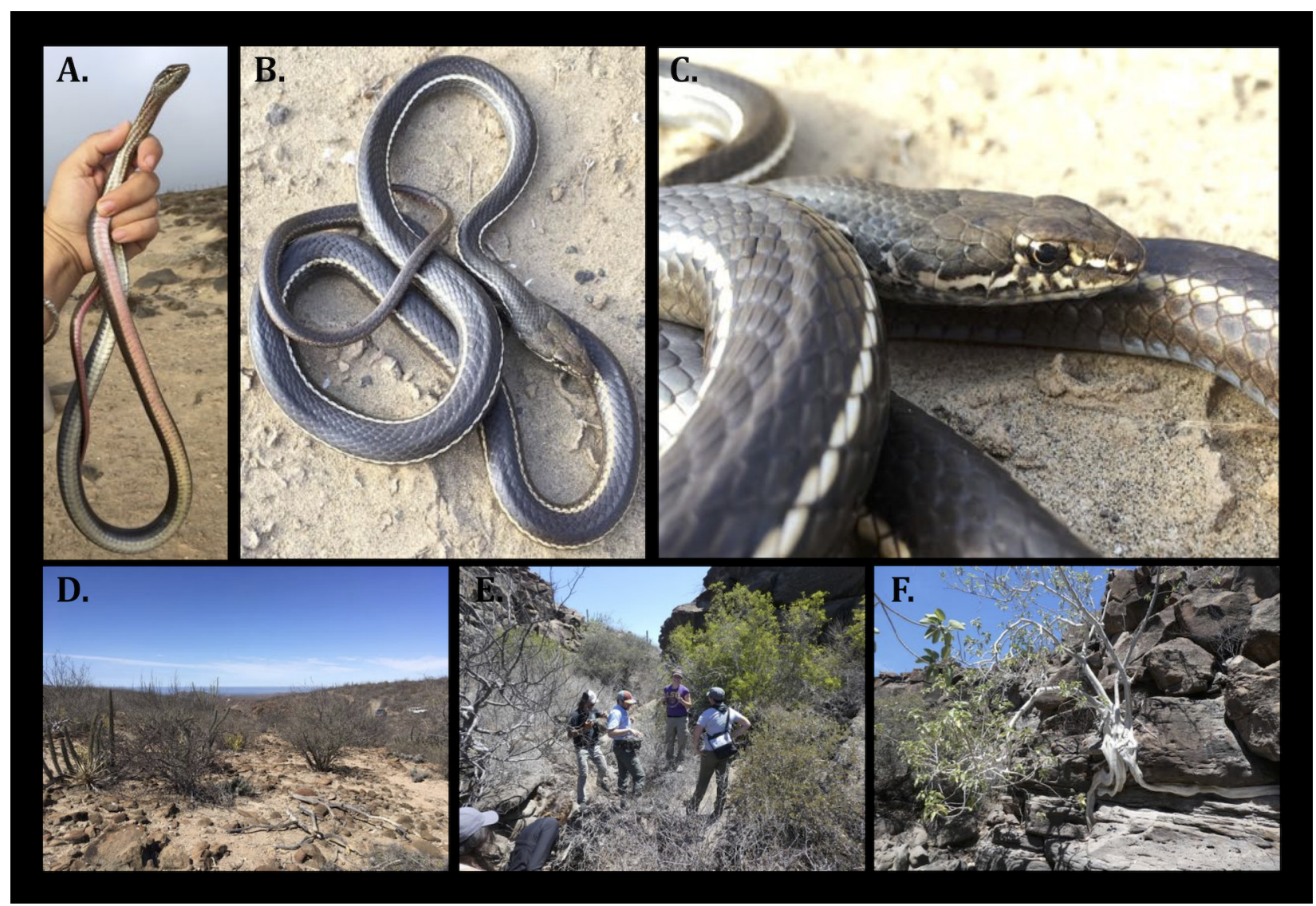

Figure 3. Masticophis lateralis individual from San Juanico Bay, Baja California Sur, Mexico. A. Ventral body view B. Dorsal body view. C. Closeup of ventral head and body. D-F. Locality and habitat where individual was found. Photographs by S. Ruane and W.B. Simison.

of Cabo San Lucas to the Magdalena plains of northwest Baja California Sur. Although the herpetofauna of Baja California Sur has been extensively documented (Murphy 1983, Grismer and McGuire 1993, Grismer 2002), this finding highlights the importance of continual taxonomic surveys serving as benchmarks for future species monitoring, conservation management, and biogeography of the Californian and Mexican deserts. 


\section{Acknowledgements}

We thank Jesse Beck for showing us the route and Victoria Aguilar for permission to enter her ranch.

\section{Authors' Contributions}

EOS, LAE, PLP, and ARS first arrived at the locality; AMG discovered the snake in the tree; SR identified the specimen; SR, EOS, and WBS photographed the specimen and locality; and AMG wrote the manuscript; all authors reviewed the manuscript.

\section{References}

Alaníz García, J (2009) Base de datos de la colección herpetológica de la Facultad de Ciencias de la Universidad Autónoma de Baja California. Universidad Autónoma de Baja California. Facultad de Ciencias. Bases de datos SNIB-CONABIO proyecto No. DC006. México DF. http://www.snib.mx/proyectos/cgi-bin/datos 2.cgi? Letras $=\mathrm{DC} \&$ Numero $=6$. Accessed 2018-06-29.

Baird SF, Girard C (1853) Catalogue of North American reptiles in the Museum of the Smithsonian Institute. Part I: Serpents. Smithsonian Institution, Washington, DC, 171 pp. https://doi.org/10.5962/ bhl.title. 5513

Bogert CM (1930) An annotated list of the amphibians and reptiles of Los Angeles County, Bulletin of the Southern California Academy of Sciences 29 (1): 3-14.

Cope E.D (1861) Contributions to the ophiology of Lower California, Mexico and Central America. Proceedings from the National Academy of Sciences Philadelphia 13: 292-306.

Cope E.D (1895). On some North American Snakes. American Naturalist 29: 676-680.

Grismer LL (1990) Relationships, taxonomy, and biogeography of the Masticophis lateralis complex in Baja California, Mexico. Herpetologica 46 (1): 66-77.

Grismer LL (2002) Amphibians and reptiles of Baja California, including its Pacific islands and the islands in the Sea of Cortés. University of California Press, Berkeley, 413 pp.

Grismer LL, Mahrdt CR (1996) Geographic distribution. Masticophis lateralis lateralis. Herpetological Review 27 (1): 34.

Grismer LL, McGuire, JA (1993) The oases of central Baja California, Mexico. Part I. A preliminary account of the relict mesophilic herpetofauna and the status of the oases. Bulletin of the Southern California Academy of Sciences 92 (1): 2-24.

Hallowell E (1853) On some new reptiles from California. Proceedings of the Academy of Natural Sciences of Philadelphia 6: 236-238.

Hammerson GA (1979) Thermal ecology of the striped racer, Masticophis lateralis. Herpetologica 35 (3): 267-273.

iDigBio (2018) http://www.idigbio.org/portal 2018. Accessed on: 2018$11-2$.

Jennings MR (1983) Masticophis lateralis (Hallowell). Striped racer. Catalogue of American Amphibians and Reptiles 343: 1-2.

Johnston MC (1971) Revision of Colubrina (Rhamnaceae). Brittonia 23 (1): 2-53.

Murphy RW (1983) Paleobiogeography and genetic differentiation of the Baja California herpetofauna. California Academy of Sciences 137: 1-48.

O'Connell KA, Streicher JW, Smith EN, Fujita MK (2017) Geographical features are the predominant driver of molecular diversification in widely distributed North American Whipsnakes. Molecular Ecology 26 (20): 5729-5751. https://doi.org/10.1111/ mec. 14295

Powell R, Conant R, Collins JT (2016) A Field Guide to Reptiles and Amphibians of Eastern and Central North America, Fourth Edition. Houghton Mifflin, Boston, 493 pp.

Riemer WJ (1954) A new subspecies of the snake Masticophis lateralis from California. Copeia 1954 (1): 45-48.

Uetz P (2012) The Reptile Database. http://www.reptile-database.org. Accessed on: 2018-11-2.

Van Denburgh J, Slevin JR (1921) Preliminary diagnoses of new species of the peninsula of Lower California, with note on the species in the collection of the Academy. Proceedings from the California Academy of Sciences 4 (11): 95-98

Wilson LD (1986) Masticophis Lateralis. Catalogue of American Amphibians and Reptiles 400: 1. 